\title{
HUBUNGAN STATUS GIZI DENGAN KEJADIAN ISPA PADA BALITA DI WILAYAH KERJA PUSKESMAS TANJUNG AGUNG KABUPATEN OGAN KOMERING ULU TAHUN 2019
}

\author{
Eichi Septiani,SKM.,M.K.M \\ Diploma III Kebidanan STIKES Al-Ma'arif Baturaja \\ Email : eichi.septiani@gmail.com
}

\begin{abstract}
ABSTRAK
Latar Belakang: Infeksi saluran pernapasan adalah penyakit infeksi yang menyerang salah satu bagian dari saluran nafas yang berlangsung selama 14 hari. Berbagai macam faktor penyebab terjadinya ISPA, salah satunya adalah status gizi yang tidak baik. ISPA merupakan salah satu penyebab utama kunjungan pasien pada sarana kesehatan. Berdasarkan data yang didapat di wilayah kerja puskesmas Tanjung Agung pada periode Januari-Maret 2019 terdapat Penderita ISPA berjumlah 391 balita. Tujuan: Untuk mengetahui Hubungan antara status gizi dengan kejadian ISPA pada balita di UPTD Puskesmas Tanjung Agung Kabupaten Ogan Komering Ulu tahun 2019. Metode: Populasi dalam penelitian adalah ibu yang memiliki balita di UPTD PuskesmasTanjung Agung Kabupaten Ogan Komering Ulu pada bulan Juli Tahun 2019 yang berjumlah 76 orang. Analisa data menggunakan analisa univariat dan analisa bivariat dengan menggunakan tabel distribusi dan uji statistik Chi-Square, dengan derajat kepercayaan 95\%. Penelitian ini menggunakan metode analitik dengan pendekatan cross sectional. Pengumpulan data dengan melalui wawancara langsung terhadap responden dengan menggunakan check list yang berkaitan dengan kejadian ISPA dan pengamatan terhadap status gizi. Hasil penelitian: Variabel yang diteliti pada penelitian ini Status Gizi pada balita dan Kejadian ISPA. Pada analisa bivariat didapatkan ada hubungan yang bermakna antara Status Gizi Balita dengan Kejadian ISPA di UPTD PuskesmasTanjung Agung Kabupaten Ogan Komering Ulu pada bulan Juli Tahun 2019 dengan p value 0,023. Kesimpulan: Ada hubungan yang bermakna antara Status Gizi Balita dengan Kejadian ISPA
\end{abstract}

\section{Kata Kunci: Kejadian ISPA, Status Gizi}

\section{ABSTRACT}

Background: Respiratory tract infection is an infectious disease that attacks one part of the respiratory tract that lasts for 14 days. Various factors cause ARI, one of which is poor nutritional status. ARI is one of the main causes of patient visits to health facilities. Based on data obtained in the working area of the Tanjung Agung puskesmas in the JanuaryMarch 2019 period, there were 391 children with ARI. Objective: To find out the relationship between nutritional status and the incidence of ARI in infants in Tanjung Agung UPTD Puskesmas Ogan Komering Ulu in 2019. Methods: The population in this study was mothers who had children under five years old at UPTD PuskesmasTanjung Agung, Ogan Komering Ulu Regency in July 2019, totaling 76 people. Data analysis uses univariate analysis and bivariate analysis using distribution tables and Chi-Square statistical tests, with a 95\% confidence level. This research uses analytic method with cross sectional approach. Collecting data through direct interviews with respondents using a check list related to ARI events and observations of nutritional status. Results: In the 
bivariate analysis there was a significant relationship between Toddler Nutrition Status and ARI in UPTD Puskesmas Agung Tanjung Ogan Komering Ulu in July 2019 with p value 0.023. Conclusion: There is a significant relationship between Toddler Nutrition Status with ARI

Keywords: ARI events, nutritional status

\section{PENDAHULUAN}

Infeksi saluran pernapasan adalah penyakit infeksi yang menyerang salah satu bagian dari saluran nafas yang berlangsung selama 14 hari. Berbagai macam faktor penyebab terjadinya ISPA, salah satunya adalah status gizi yang tidak baik. ISPA merupakan salah satu penyebab utama kunjungan pasien pada sarana kesehatan (Pamela dkk, 2016).

Menurut World Health Organization (WHO) lebih dari 50\% kematian bayi dan anak terkait dengan gizi buruk, 13 juta anak balita di dunia meninggal setiap tahun dengan angka kematian balita di atas 40 per 1000 kelahiran hidup adalah 15\%-20\% pertahun pada golongan usia balita. Sebagian besar kematian tersebut terdapat di Negara berkembang, di mana ISPA (pneumonia) merupakan salah satu penyebab utama kematian dengan membunuh empat juta anak balita setiap tahun (Sofyan, I. 2015).

Hasil survei oleh South East Asian Nutrition Surveys (SEANUTS) tahun 2012 terhadap sembilan Negara (Indonesia, Malaysia, Thailand, Filipina,
Kamboja, Vietnam, Srilanka, Myanmar, dan Timor Leste) mensyatakan, gizi buruk di Indonesia masih menjadi masalah utama. Indonesia menempati di urutan kelima di Asia untuk gizi buruk balita terbanyak yakni 28\%. Sementara ISPA merupakan penyebab utama kematian bayi di Asia, Sebanyak 2,1 juta balita meninggal karena ISPA, berdasarakan data pada tingkat regional Asia Tenggara 2002 - 2010 adalah $19 \%$ episode batuk pilek pada balita menderita ISPA tersebut merupakan pneumonia Berat.(Suryadi, 2013).

Di Indonesia, ISPA masih merupakan salah satu masalah kesehatan masyarakat yang utama, hal ini disebabkan karena masih tingginya angka kematian bayi dan balita karena ISPA yaitu 6 per 1000. Setiap anak diperkirakan 3-6 episode mengalami ISPA setiap tahunnya dan $40 \%-60 \%$ kunjungan Puskesmas adalah pendrita ISPA (Niken dkk, 2014).

Angka kematian bayi, balita dan anak merupakan salah satu indikator kesehatan yang sangat mendasar. Berdasarkan hasil Survei Kesehatan 
Rumah Tangga (SKRT) tahun 2007, menunjukkan bahwa proporsi kematian bayi akibat ISPA di Indonesia adalah sebesar 30,8\%, artinya dari 100 bayi meninggal, 30 diantaranya meninggal karena ISPA.

ISPA masih merupakan penyebab kematian terbanyak pada balita, yakni sebesar 22,8\% atau sebesar 4,6 kematian per 1000 balita. Tingginya angka kejadian ISPA pada balita disebabkan oleh beberapa faktor, antara lain keadaan gizi yang buruk pada balita. Balita dengan gizi yang kurang akan lebih mudah terserang ISPA dibandingkan balita dengan gizi normal, karena factor daya tahan tubuh yang kurang. Penyakit infeksi akan menyebabkan balita tidak mempunyai nafsu makan dan berakibat kekurangan gizi. Pada keadaan gizi kurang, balita akan lebih mudah terserang ISPA berat bahkan serangannya lebih lama.

Status gizi balita merupakan hal penting yang harus diketahui oleh setiap orangtua. Perlunya perhatian lebih dalam tumbuh kembang di usia balita didasarkan fakta bahwa kurang gizi yang terjadi pada masa emas ini akan berpengaruh pada kualitas tumbuh kembang anak (Widya, 2017).

Balita merupakan kelompok masyarakat yang rentan terhadap gizi kurang, pada kelompok tersebut mengalami siklus pertumbuhan dan perkembangan yang membutuhkan zat gizi yang lebih besar dari kelompok umur yang lain sehingga balita paling mudah menderita kelainan gizi. Kejadian gizi buruk seperti fenomena gunung es dimana kejadian gizi buruk dapat menyebabkan kematian. Pada kasus gizi kurang, akan lebih rentan terhadap infeksi akibat menurunnya kekebalan tubuh terhadap invasi patogen. Pertumbuhan yang baik dan status imunologi yang memadai akan menghasilkan kesehatan yang baik pula (Widya, 2017).

Hasil penelitrian Nelly, dkk, 2017 menunjukkan ada hubungan status gizi dengan kejadian ISPA di wilayah kerja Puskesmas Margaharja Sukadana Ciamis dimana pvalue $=0,000(\mathrm{p}<0,005)$.

Zat gizi (makanan) memiliki efek kuat untuk reaksi kekebalan tubuh dan resistensi terhadap infeksi. Hal ini dibuktikan dengan adanya hasil penelitian akhir-akhir ini yang memperlihatkan bahwa melalui pemberian gizi, dan hormon anabolik dapat mengatur daya tahan (resistensi) hospes terhadap infeksi bakteri. Keadaan Kurang Energi Protein (KEP), ketahanan tubuh menurun dan virulensi patogen lebih kuat sehingga menyebabkan 
keseimbangan yang terganggu dan akan mudah terjadi infeksi. Salah satu determinan utama dalam mempertahankan keseimbangan tersebut adalah status gizi (niken dkk, 2014).

Berdasarkan data yang didapat di wilayah kerja puskesmas Tanjung Agung pada tahun 2018 periode JanuariDesember menyebutkan bahwa sebanyak 1.950 balita dengan penderita ISPA sebanyak 211 balita. Pada tahun 2019 periode Januari-Maret terdapat Penderita ISPA berjumlah 391 balita (profil Puskesmas Tanjung Agung, 2019).

Berdasarkan keterangan diatas maka peneliti tertarik untuk mengambil penelitian tentang Hubungan antara status gizi dengan kejadian ISPA pada balita di UPTD Puskesmas Tanjung Agung Kabupaten Ogan Komering Ulu tahun 2019.

\section{METODE PENELITIAN}

Penelitian dilakukan observasional dengan desain study Cross Sectional yaitu menguji Variabel Independen (status gizi) dengan kejadian ISPA (Variabel Dependen) dikumpulkan secara bersama-sama (Notoatmodjo, 2010).
Penelitian ini dilakukan di UPTD Puskesmas Tanjung Agung Kabupaten Ogan Komering Ulu tahun 2019. Waktu penelitian dilaksanakan pada bulan AprilMei 2019

Populasi pada penelitian ini adalah ibu yang memiliki balita di di UPTD Puskesmas Tanjung Agung Kabupaten Ogan Komering Ulu tahun 2019 yang berjumlah 76. Sampel adalah bagian dari populasi yang di ambil pada saat penelitian, Sampel pada penelitian ini adalah total populasi yang berjumlah 76 yaitu ibu yang memiliki balita yang berada di UPTD Puskesmas Tanjung Agung.

\section{HASIL PENELITIAN}

Berdasasarkan hasil analisis univariat didapatkan dari 76 responden didapatkan 59 responden $(77,6 \%)$ yang mengalami ISPA dan 17 responden $(22,4 \%)$ yang tidak mengalami ISPA sebanyak Serta terdapat 67 responden $(88,2 \%)$ dengan status gizi balita kurang baik dan 9 responden $(11,8 \%)$ dengan gizi balita baik. 
Tabel 5.3

Hubungan Status Gizi Balita dengan kejadian ISPA pada balita di Wilayah Kerja UPTD Puskesmas Tanjung Agung Kabupaten Ogan Komering Ulu tahun 2019

\begin{tabular}{|c|c|c|c|c|c|c|c|c|}
\hline \multirow{3}{*}{ No } & \multirow{3}{*}{ Status Gizi Balita } & \multicolumn{4}{|c|}{ Kejadian ISPA } & \multirow{2}{*}{\multicolumn{2}{|c|}{ Jumlah }} & \multirow{3}{*}{$\begin{array}{c}\mathrm{P} \\
\text { value }\end{array}$} \\
\hline & & \multicolumn{2}{|c|}{$\mathrm{Ya}$} & \multicolumn{2}{|c|}{ Tidak } & & & \\
\hline & & $\mathrm{f}$ & $\%$ & $\mathrm{f}$ & $\%$ & $\mathrm{f}$ & $\%$ & \\
\hline 1 & Baik & 55 & 82,1 & 12 & 17,9 & 67 & 100 & \multirow[b]{2}{*}{0,023} \\
\hline 2 & Kurang Baik & 4 & 44,4 & 5 & 55,6 & 55 & 100 & \\
\hline & Jumlah & 59 & 77,6 & 17 & 53,9 & 76 & 100 & \\
\hline
\end{tabular}

Analisa ini dilakukan untuk mengetahui hubungan antara variabel dependen (Kajadian ISPA) serta variabel independen (Status Gizi Balita). Uji statistik yang digunakan adalah uji chisquare dengan batas kemaknaan $\mathrm{p}$ value 0,05 artinya ada hubungan yang bermakna (signifikan) dan bila $\mathrm{p}$ value > 0,05 maka tidak ada hubungan yang bermakna.

Hubungan Status Gizi Balita dengan kejadian ISPA pada balita

Berdasarkan tabel 5.3 dapat dilihat bahwa responden yang mengalami ISPA pada responden dengan status gizi baik yaitu sebanyak 55 responden $(82,1 \%)$ dan responden bahwa responden yang mengalami ISPA pada responden dengan status gizi kurang baik yaitu sebanyak 4 responden (44,4\%). Hasil Uji statistik chi square diperoleh value $=0,023$, ini berarti ada hubungan yang bermakna antara status gizi balita dengan kejadian ISPA.

\section{PEMBAHASAN}

Pada hasil analisa biavariat dapat dilihat responden yang mengalami ISPA pada responden dengan status gizi baik yaitu sebanyak 55 responden $(82,1 \%)$ dan responden bahwa responden yang mengalami ISPA pada responden dengan status gizi kurang baik yaitu sebanyak 4 responden $(44,4 \%)$.

Hasil Uji statistik chi square diperoleh value $=0,023$, ini berarti ada hubungan yang bermakna antara status gizi balita dengan kejadian ISPA. Maka hipotesa yang menyatakan ada hubungan yang bermakna antara status gizi balita dengan kejadian ISPA terbukti.

Hasil penelitrian ini sejalan dengan hasil Nelly, dkk, 2017 menunjukkan ada hubungan status gizi dengan kejadian ISPA di wilayah kerja Puskesmas 
Margaharja Sukadana Ciamis dimana pvalue $=0,000(p<0,005)$.

Gizi merupakan salah satu faktor penting yang menentukan tingkat kesehatan dan kesejahteraan manusia.. Tingkat keadaan gizi optimal akan tercapai apabila konsumsi gizi makanan pada seseorang tidak seimbang dengan kebutuhan tubuh mereka.

Dimana status gizi juga dapat mempengaruhi kekebalan tubuh balita karena jika balita menderita gizi buruk dan telah diimunisasi lengkap maka akan terserang penyakit.

\section{KESIMPULAN}

Hasil penelitian yang telah dilaksanakan di wilayah kerja UPTD Puskesmas Tanjung Agung Kecamatan Baturaja Barat Kabupaten Ogan Komering Ulu tahun 2019, didapatkan ada hubungan yang bermakna antara status gizi balita dengan kejadian ISPA dengan nilai $p$ value 0,023 .

\section{DAFTAR PUSTAKA}

1. Depkes RI, 2009, Status Gizi Anak Balita, www.depkes.go.id

2. Depkes RI, 2011. Ditjen PPM \& PLP, Pedoman Program Pemberantasan Penyakit ISPA. Jakarta

3. Hanif, 2013. Hubungan status gizi terhadap terjadinya infeksi saluran pernafasan akut (ISPA) pada balita di Puskesmas Pajang Surakarta. Naskah Publikasi. Fakultas Kedokteran Muhammadiyah, Surakarta Muhammadiyah, Surakarta; 2013.

4. Harahap, S. 2011. Analisis Faktor Risiko Yang Berhubungan Dengan Kejadian Pneumonia Pada Anak Balita Di RSUD Pasar Rebo Jakarta. Jakarta : Universitas Indonesia

5. Hidayat, Alimul Azis. 2010. Metode Penelitian Kebidanan Teknik Analisa Data. Jakarta: Salemba Medika.

6. Juslan Andari,2011. Beberapa faktor yang berhubungan dengan kejadian ISPA pada balita di pemukiman nelayan tambak lorok kelurahan tanjungmas semarang utara, Semarang.

7. Kementerian Kesehatan RI. 2013.Buletin Jendela Epidemiologi Volume 3. Jakarta : Kemenkes RI.

8. Lidia Widia. 2017.Hubungan Antara Status Gizi dengan Kejadian ISPA pada balita. Jurnal Darul Azhar.

9. Machmud R , 2012 . Pneumonia Balita di Indonesia dan Peran Kabupaten dalam

10. Menanggulanginya. Padang:Andalas University.

11. Neli Sunarni, Resna Litasari, Lela Deis, 2017. Hubungan Status Gizi dengan Kejadian ISPA pada Balita di 
Wilayah Kerja Puskesmas

Margaharja Sukadana Ciamis.

Sekolah Tinggi Ilmu Kesehatan

Muhammadiyah Ciamis

12. Niken Puji Lestari, Lily Kresnowati, Kriswiharsi Kun Saptorini, 2014. Faktor Risiko Yang Berhubungan Dengan Kejadian Ispa Pada Bayi Dan Balita Di Wilayah Kerja Puskesmas Purwoyoso Semarang. Program Studi Kesehatan Masyarakat Fakultas Kesehatan Universitas Dian Nuswantoro Semarang

13. Notoatmodjo, S. 2012. Metodologi

Penelitian Kesehatan Edisi Revisi.

Jakarta: PT Rineka Cipta

14. Pamela Felita, Hendrik Kurniawan, Anna Maria Dewajanti. 2016. Hubungan Status Gizi dengan Kejadian Infeksi Saluran Pernapasan Akut pada Balita di Puskesmas Kecamatan Kebon Jeruk Bulan Agustus 2016. Fakultas Kedokteran Universitas Kristen Krida Wacana

15. Purnama Widoyono, 2012. Penyakit Tropis, Epidemiologi, Penularan, Pencegahan \& Pemberantasannya, Edisi kedua, Semarang.

16. Roesli, U. 2011. Inisiasi Menyusu Dini Plus ASI Eksklusif .Jakarta : Pustaka Bunda
17. Santoso, dkk, 2009. Kesehatan dan Gizi. PT Rineka Cipta dan PT Bina Adiaksara : Jakarta

18. Soekirman. 2005. Pengertian Gizi. http://.polapengasuhanorangtua.com

19. Sofyan., Iyan. (2015). Data World Heart Organization (WHO) Tentang Phenomonia Di Negara Berkembang. Diakses Pada Tanggal 25 April 2015, dari Http://www.academia.edu.com

20. Suryadi. (2013). Hasil survey oleh South East Asian Nutrition Surveys (SEANUTS) Tahun 2012 Tentang ISPA dan Gizi Buruk. Diakses Pada Tanggal 25 April 2015, dari http://www.bkmp.go.id

21. Tedjo, 2012. Imusisasi Dasar Anak. Jakarta: EGC

22. Unaids, 2012, Perawatan Ibu Hamil dan Bayi, Jakarta, Pustaka Sinar Harapani

23. Winarta 2010. Faktor yang berhubungan dengan kejadian ISPA pada nak balita di Desan Bontongan Kabupaten Enrekang. Makasar: UHM

24. WHO. Pencegahan dan pengendalian infeksi saluran pernapasan akut (ISPA) yang cenderung menjadi epiAdemik dan pandemi di fasilitas pelayanan kesehatan.[Internet]. 2007. 